\title{
MONITORING OF THE STATE OF SOCIAL AND RELATIONS OF THE ENTERPRISE
}

\section{Olena Dragan ${ }^{1}$ \\ Liana Maznik ${ }^{2}$}

DOI: https://doi.org/10.30525/978-9934-588-38-9-27

\begin{abstract}
The innovative oriented society envisages the forming of new socially responsible labour relations. This range of problems is especially actual for the enterprises of food industry. The research is undertaken on the materials of Private Joint Stock Company "Monomakh" that runs tea business in Ukraine. Economic and mathematical methods are applied in the article: expert questioning, integral evaluation, taxonomical analysis. The object of the research is the process of social and labour relations state on Private Joint Stock "Monomakh". Taking into account the specific of enterprises of food industry, there is the necessity of forming the monitoring system of social and labour relations state. The next component systems are following: normatively-legal providing, motivational providing, providing of normal terms of labour safety, organizationally staffing, sociocultural providing and development of personnel. For estimation of monitoring system efficiency of social and labour relations (SLR) state of the enterprise methodology that provides determinations single indexes, that characterize SLR; realization of ponderability estimation of monitoring system's constituents of social and labour relations by the expert workers' interviewing by Private Joint Stock Company "Monomakh" estimation of expert group coordination; determination of reviewer expert; the use of reviewer scale for calculation of integral index of SLR state; calculation of taxonomical index of SLR level; comparison of integral and taxonomical analysis results of SLR level are given. The taxonomy index of monitoring system of social and labour relations state is unstable. Beginning from 2016 had the tendency to the increase, and attained the maximum in $2017-0,416$,
\end{abstract}

\footnotetext{
${ }^{1}$ Doctor of Economic Sciences, Professor,

National University of Food Technologies, Ukraine

${ }^{2}$ Candidate of Economic Sciences, Associate Professor,

National University of Food Technologies, Ukraine
} 
but in 2018 the index diminished - 0,203, that testifies to the improper management of monitoring system of social and labour relations state on Private Joint Stock "Monomakh". Precisely this conclusion was done on the results of integral evaluation. It is necessary to improve every indicator of influence separately for improvement of social and labour relations state, monitoring of which is effective exactly with application of corresponding taxonomical index and integral evaluation. The reasonable system of SLR state monitoring of the enterprise will allow to form a valuable InfoBase about existent areas of concern and work out events in relation to provide effective strategic development of SLR of the enterprise.

\section{Introduction}

Modern market differs in numerous challenges and risks and accompanied by the high level of competition among the enterprises of food industry for the most market expanding, bringing in greater part of potential consumers and achievement of leading position. Competition compel enterprises to be in the permanent search of new inventories for minimization of charges. Many companies do not absolutely analyze and do not engage in the search of own inventories in relation to the effectiveness increase. Widespread concepts "labour inventories", "social inventories", "inventories of labour productivity" are connected with functioning of the productive system of the enterprise and do not represent modern conceptions of socio-economic development of companies. At the same time with the increasing role of a person in productive process, there is overcosting of traditional values and traced conformity of forming of social over orientation production that results in enriching its social essence. The innovative oriented society, first of all, envisages forming of new socially responsible labour relations. The development of public production, influence of scientific and technical progress and socio-economic aspiration, logically result in the necessity of searching inventories production, due to the improvement of social and labour relations on the enterprise. This range of problems is especially actual for the enterprises of food industry, that need intellectual labour of highly skilled specialists, apply innovative hi-tech equipment, have different complication labour condition, collective forms of labour organization, specific factors of goods productions, that influence on stress resistance, intercommunication and conflict of workers and as a result models influence of their labour behavior. 


\section{Analytical literature review}

Analysis of scientific publications [1-17] testifies that different aspects of social and labour relations of the enterprise is not pay much attention nowadays. Many researches are devoted to the questions of social and labour relations regulation [1-17], which authors describe on -macro, -meso, and -micro levels. At the same time the scientists don't pay much attention to the fact that from the quality of personnel cooperation, the level of trust between leaders and inferiors, to security of vitally important necessities, workers' interests, their development and self-realization are depend on the socio-economic state, increase of competitiveness positions of the enterprises at the market. Therefore, in the context of providing effective management socio-economic development of the enterprise actual orientation on determination of social and labour relations state with the aim of their improvement on the prospect is needed. Social and labour relations are relations that predefined by labour activity, that arise up and develop with the aim of labour life quality regulation; such relations come from the agreement between an employee and employer about the duties of the personal implementation by an employee on requiring payment principles of corresponding labour functions [2]. At the same time at the modern necessity of scientific and technical progress' events, total computerization, considerable labour mobility, development of IT-technologies, labour becomes complicated. Thus, the character of labour changes in the direction of its intellectualization, strengthening of work and creativity with direct influence on development of workers. It requires new approaches to the labour organization, organization of productive processes, passing to the flexible forms of organization of both labour and management, increase of necessity of worker's professional preparation, providing of deserving terms of labour and others. Therefore, social constituent becomes into the first place for searching the inventory improvements, namely, an improvement of social and labour relations state on the enterprise.

\section{Object and methods of researches}

The object is the research process of social and labour relations state on Private Joint Stock Company "Monomakh". The subject is the research is theoretical aspects and methodical approaches to the development of monitoring system of social and labour relations state on the enterprise. Research 
methods. Economic and mathematical methods are applied in the article: expert questioning, integral evaluation, taxonomical analysis.

\section{Results of researches}

It is suggested to work out the monitoring system of social and labour relations state of the enterprise according to the following stages:

I. Explaining of the monitoring system of social and labour relations state of the enterprise. The system will have been worked out with the representatives of human department, department of labour health and safety protection, and other departments, that are related to SLR for formulation of aims, development of events in relation to the improvement of social and labour relations state for the next period.

I. Explaining of the monitoring system of social and labour relations state of the enterprise. The system will have been worked out with the representatives of human department, department of labour health and safety protection, and other departments, that are related to SLR for formulation of aims, development of events in relation to the improvement of social and labour relations state for the next period.

II. Determination of basic constituents of monitoring system of social and labour relations state of the enterprise. By the method of experts questioning of questions of Private Joint Stock Company "Monomakh" personnel were determined the following compositions: normatively-legal providing (In), motivational providing (Im), providing of normal terms of labour safety (Ip), organizationally-skilled providing (Io), socio-cultural providing and personnel development (Is) for monitoring the social and labour relations state.

III. Choice of indexes that characterize every constituent of the monitoring system of social and labour relations state of the enterprise is shown in the table 1.

$I V$. Estimation of complex index of the component monitoring system of social and labour relations state of the enterprise. On the basis of single indexes is suggested to determine by formula

$$
I i=\left(I i_{1}+I_{i 2}+I_{i 3}\right)
$$

$V$. Determination of every constituent ponderability by expert way at determining the integral index of monitoring system of SLR state of the enterprise. 


\section{Indexes of constituents of the monitoring system of the SLR state of the enterprise}

\begin{tabular}{|c|c|}
\hline № & Name of indexes \\
\hline 1 & 2 \\
\hline & Normatively-legal providing (In) \\
\hline 1 & $\begin{array}{l}* \text { Coefficient of collective agreement implementation of the enterprise in part of } \\
\text { socially labour relations (SLR) } *\left(I n_{1}\right)\end{array}$ \\
\hline 2 & $\begin{array}{l}\text { *Coefficient of new instructions development, positions, regulations in the field } \\
\text { of SLR* }\left(\operatorname{In}_{2}\right)\end{array}$ \\
\hline 3 & Amount of labour discussions, conflicts that arose up for a year on the enterprise $\left(I_{3}\right)$ \\
\hline & Motivational providing (Im) \\
\hline 1 & Wage-fund of workers, thousands of hrn. $\left(\operatorname{Im}_{1}\right)$ \\
\hline 2 & Bonuses fund of workers, thousands of hrn. $\left(\operatorname{Im}_{2}\right)$ \\
\hline 3 & Charges on personnel, thousand of hrn. $\left(\operatorname{Im}_{3}\right)$ \\
\hline & Providing of normal safe terms of labour (Ip) \\
\hline 1 & Charges on labour protection healthy and safety, thousand of hrn. $\left(I p_{1}\right)$ \\
\hline 2 & Coefficient of industrial injuries $\left(I p_{2}\right)$ \\
\hline 3 & $\begin{array}{l}\text { Quantity of workers t who passed advanced training on questions of labour } \\
\text { health and safety, persons }\left(I p_{3}\right)\end{array}$ \\
\hline & Organizationally-skilled providing (Io) \\
\hline 1 & Coefficient of fluidity $\left(I o_{1}\right)$ \\
\hline 2 & Labour productivity, thousand t/persons $\left(\mathrm{IO}_{2}\right)$ \\
\hline 3 & Part of manual operation, \% $\left(\mathrm{IO}_{3}\right)$ \\
\hline & Sociocultural providing and personnel development (IS) \\
\hline 1 & Charges on social package per employee, hrn. $\left(I s_{1}\right)$ \\
\hline 2 & Charges on sociocultural events, thousands of hrn. $\left(I s_{2}\right)$ \\
\hline 3 & Quantity of workers, who passed advanced training, got higher education, persons $\left(I S_{3}\right)$ \\
\hline
\end{tabular}

*The coefficient of collective agreement implementation of the enterprise in the part of socially labour relations (SLR) is determined as the relation of unfulfilled points of collective agreement in the part of SLR to the general amount of points.

*The coefficient of new instructions development, positions, regulations in the field of $S L R^{*}$ is determined as the relation of the amount of instructions positions, regulations, worked out annualy in the field of SLR to the general amount of documents (positions, instructions and other). 
The integral index of monitoring system of SLR state of the enterprise (II SLR state) is suggested to determine by formula:

$$
\text { IISLR state }=\alpha \cdot \operatorname{In}+\beta \cdot \operatorname{Im}+\gamma \cdot \operatorname{Ip}+\delta \cdot I o+£ \cdot I s
$$

where In, Im, Ip, Io, Is accordingly complex index of monitoring system's component of SLR; $\alpha, \beta, \gamma, \delta$, $£$ is ponderability resulting of monitoring system's component of SLR. The investigated enterprise is Private Joint Stock Company "Monomakh" is a pioneer of tea business in Ukraine. Nowadays company occupies about $15 \%$ of Ukrainian tea market, geographical expanding of tea raw material supplying is broadening constantly. In 2018 the market value of company is estimated in $\$ 14$ million, net profit from products realization was 473577 thousand hrn., profit - 6764 thousand hrn., quantity of workers was 272 persons, high level of manual operations - of $38,4 \%$.

For realization of ponderability estimation of monitoring system's constituents of social and labour relations state on Private Joint Stock Company "Monomakh" the interview of 10 experts was conducted, that have necessary experience of food enterprises subdivisions management, and they hold next positions (accountant, sales managers, logistician, traffic manager, human resources representative) on the investigated enterprise. Among them there are only the 1 st and 4th experts work as leaders on Private Joint Stock Company "Monomakh". The results are presented in table 2.

Conduct the analysis of coordination of experts' opinion by system of indexes, that envisages the analysis of interview results' variation (table 3).

The values of variation indexes testify to coordination of expert estimations on the separate constituents of monitoring system of social and labour relations state. Thus, exceeding absent of critical value $\left(C V_{\sigma}(x) \leq 0,33\right)$, the group, mainly, homogeneous. Most coordination is observed for a constituent «organizationally and human resourcing», and the least is «normatively-legal providing» [20].

Analytical research with coliciting of variation characteristics' degree provides the analysis of coordination exceptionally separate indexes is undertaken. The estimation of coordination of expert group on the whole is based on the calculation of plural coefficient of range correlation (concordance coefficient). For this purpose, the results of interview transform in range scale (table 4). 


\section{Olena Dragan, Liana Maznik}

\begin{tabular}{|c|c|c|c|c|c|c|c|c|}
\hline \multirow{15}{*}{ 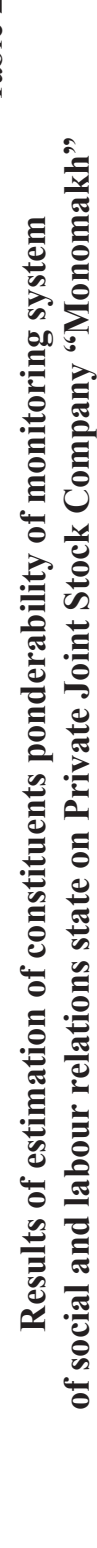 } & \multirow{2}{*}{ 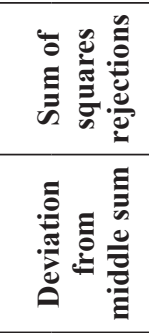 } & \multicolumn{7}{|c|}{ 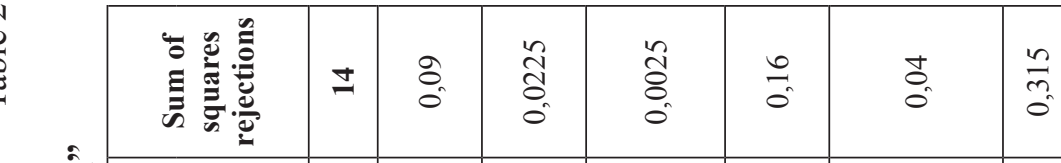 } \\
\hline & & 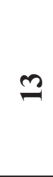 & $\tilde{o}^{n}$ & $\frac{n}{0}$ & $\begin{array}{l}n \\
0 \\
0\end{array}$ & $\stackrel{+}{\dot{\sigma}_{1}}$ & గn & $\begin{array}{l}8 \\
0 \\
0\end{array}$ \\
\hline & 念 & $\mathcal{工}$ & $\cong$ & $\frac{n}{i}$ & $\stackrel{n}{\sim}$ & $\stackrel{+}{\sim}$ & $\stackrel{\infty}{\sim}$ & $ㅇ$ \\
\hline & 으 & $\Xi$ & $\frac{n}{0}$ & $\tilde{\sigma}^{n}$ & గn & $\tilde{0}^{n}$ & $\frac{n}{0}$ & - \\
\hline & $a$ & 으 & గn & $\frac{n}{0}$ & $\frac{n}{0}$ & $\overbrace{0}^{n}$ & ๙ָ & - \\
\hline & $\infty$ & $a$ & $\frac{n}{0}$ & $\hat{o}$ & $\tilde{o}$ & $\frac{n}{0}$ & ָூ & - \\
\hline & $r$ & $\infty$ & N & $\frac{n}{0}$ & గ్ & $\tilde{\sigma}^{n}$ & $\frac{n}{0}$ & - \\
\hline & $\stackrel{n}{=}$ & $\infty$ & $\frac{n}{0}$ & $\tilde{\sigma}^{n}$ & $\tilde{\sigma}^{2}$ & $\frac{n}{0}$ & గ్ & - \\
\hline & $\frac{2}{4}$ & $r$ & ํ. & $\frac{n}{0}$ & $\tilde{\sigma}_{0}$ & $\mathfrak{o}^{n}$ & $\frac{n}{0}$ & - \\
\hline & $\nabla$ & 0 & $\frac{n}{0}$ & r. & $\frac{n}{0}$ & $\hat{o}^{n}$ & Nু & - \\
\hline & $m$ & $n$ & $\frac{n}{0}$ & $\tilde{o}^{2}$ & $\frac{n}{0}$ & గn & గ̂ & - \\
\hline & $N$ & $\nabla$ & $\overbrace{0}^{N}$ & $\tilde{m}^{n}$ & $\frac{n}{0}$ & గn & $\frac{n}{0}$ & - \\
\hline & - & $m$ & $\frac{n}{6}$ & $\tilde{\sigma}$ & $\frac{n}{0}$ & $\stackrel{m}{0}$ & 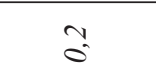 & - \\
\hline & 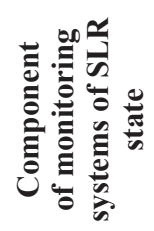 & $N$ & 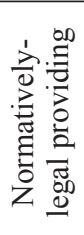 & 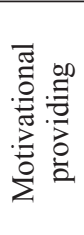 & 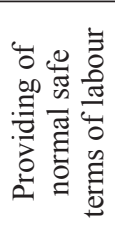 & 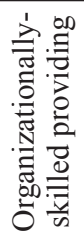 & 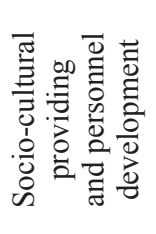 & $\stackrel{\pi}{0}$ \\
\hline & 岏 & - & - & $N$ & $m$ & $\nabla$ & in & \\
\hline
\end{tabular}


Chapter «Economic sciences»

\begin{tabular}{|c|c|c|c|c|c|c|c|c|}
\hline 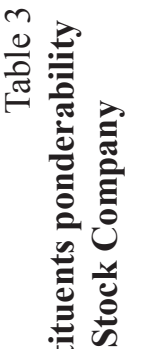 & 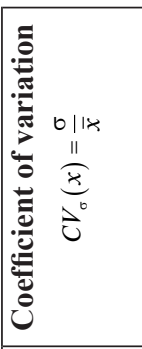 & 0 & 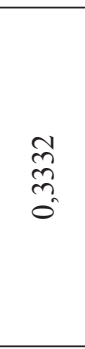 & $\begin{array}{l}0 \\
\text { రి } \\
\text { m. } \\
0\end{array}$ & $\begin{array}{l}\text { J } \\
\text { m } \\
0\end{array}$ & $\begin{array}{l}\text { J } \\
\infty \\
\\
0\end{array}$ & $\begin{array}{l}n \\
\text { N } \\
\text { ? } \\
0\end{array}$ & $\frac{n}{m}$ \\
\hline 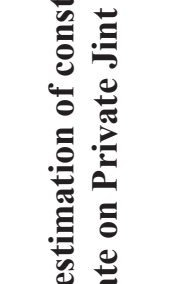 & 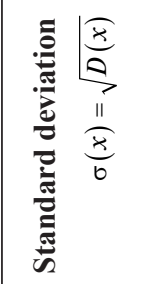 & $n$ & $\begin{array}{l}\overrightarrow{\widetilde{N}} \\
\text { त̃ } \\
0\end{array}$ & $\begin{array}{l}\text { స్ } \\
\text { స్ } \\
\text { o }\end{array}$ & 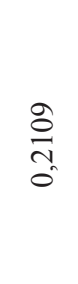 & 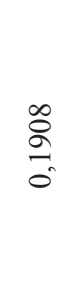 & \begin{tabular}{l}
$\frac{2}{\pi}$ \\
\multirow{2}{*}{}
\end{tabular} & $\begin{array}{l}\stackrel{8}{8} \\
\text { तु } \\
\text { - }\end{array}$ \\
\hline 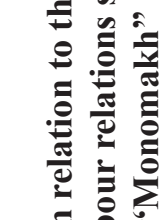 & 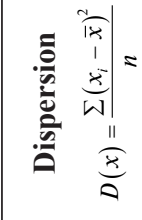 & $\nabla$ & 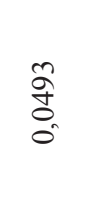 & $\begin{array}{l}\infty \\
\stackrel{0}{0} \\
0 \\
0 \\
0\end{array}$ & 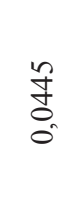 & $\begin{array}{l}\text { to } \\
\text { ర్ } \\
0 \\
0\end{array}$ & $\begin{array}{l}\stackrel{+}{+} \\
\stackrel{+}{0} \\
0\end{array}$ & $\begin{array}{l}\hat{m} \\
\dot{0} \\
0\end{array}$ \\
\hline 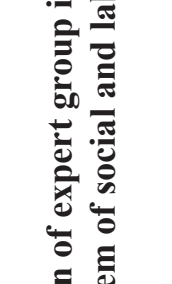 & 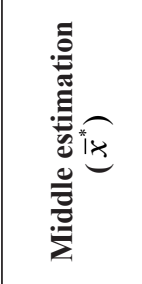 & $m$ & $\overrightarrow{0}$ & $\begin{array}{l}n \\
\tilde{n} \\
0\end{array}$ & $\frac{n}{2}$ & 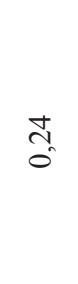 & $\stackrel{\infty}{\overrightarrow{0}}$ & $\stackrel{\circ}{\rightarrow}$ \\
\hline 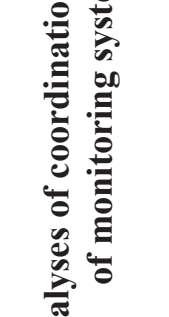 & 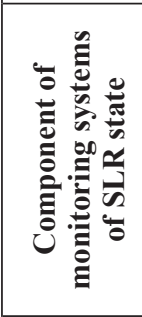 & $N$ & 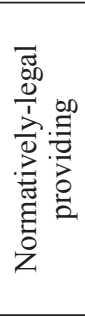 & 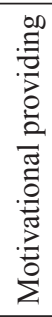 & 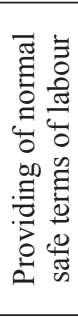 & 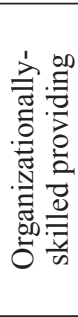 & 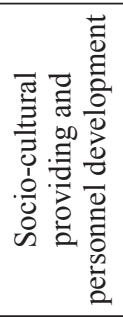 & 吾 \\
\hline & 年 & - & - & $N$ & $m$ & $\nabla$ & $n$ & \\
\hline
\end{tabular}




\section{Olena Dragan, Liana Maznik}

\begin{tabular}{|c|c|c|c|c|c|c|c|}
\hline \multirow{15}{*}{ 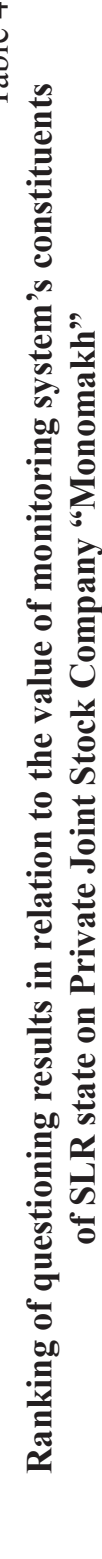 } & \multirow{2}{*}{ 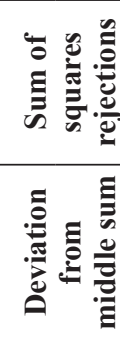 } & \multicolumn{6}{|c|}{ ש。 } \\
\hline & & † & $\stackrel{7}{1}$ & 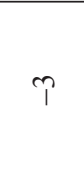 & 국 & $r$ & 0 \\
\hline & E & $\stackrel{\bullet}{\sim}$ & $\underline{n}$ & $\hat{\sim}$ & 守 & $\hat{n}$ & 은 \\
\hline & 음 & $\neg$ & $N$ & $\nabla$ & $n$ & $m$ & $\cong$ \\
\hline & $a$ & - & $\sim$ & $\nabla$ & $n$ & $m$ & $n$ \\
\hline & $\infty$ & $N$ & - & $\nabla$ & $n$ & $m$ & 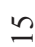 \\
\hline & $r$ & N & - & $m$ & $\nabla$ & $n$ & 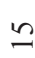 \\
\hline & $\stackrel{0}{=}$ & $\nabla$ & $\sim$ & - & $n$ & $m$ & $\because$ \\
\hline & 忞 & $n$ & - & $N$ & $\nabla$ & $m$ & 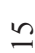 \\
\hline & $\nabla$ & $m$ & - & $N$ & $n$ & $\nabla$ & $\cong$ \\
\hline & $m$ & $m$ & - & $N$ & $\nabla$ & $n$ & $\cong$ \\
\hline & $N$ & $\sim$ & - & $m$ & $n$ & $\nabla$ & 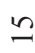 \\
\hline & - & $m$ & - & $\sim$ & $n$ & $\nabla$ & 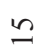 \\
\hline & 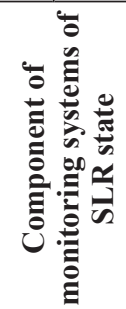 & 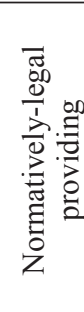 & 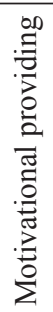 & 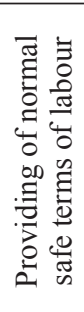 & 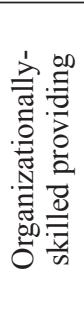 & 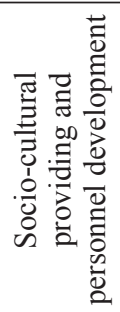 & 要 \\
\hline & $\frac{01}{\zeta}$ & - & $\sim$ & $m$ & $\nabla$ & $n$ & \\
\hline
\end{tabular}


For estimation the coordination of experts' opinions totally for five constituents, we will take concordance coefficient. This plural coefficient of range correlation is the measure of educted range estimations reliability (Kendall's coefficient).

We will use the educted intermediate calculations for determination of Kendall's coefficient and estimations of its importance. In calculations we used formula [4, p. 247-248]:

$$
W=\frac{12 * S}{m^{2}\left(n^{3}-n\right)}
$$

$m-$ is the amount of expert (expert number $i=\overline{1,10}$ );

$n-$ is the amoun of indexes (index number $j=\overline{1,5}$ );

$S-$ is a sum of rejections squares of grades sum of $j$ of the component monitoring system of SLR state from the average value of grades sum of all constituents.

$$
S=652, n=5, m=10
$$

Thus, the value of concordance coefficient is:

$$
W=\frac{12 * 652}{10^{2}\left(5^{3}-5\right)}=0,652
$$

It is the certificate of high degree of experts' opinions coordination. For estimation of unchance of such value we will take the Pearson criterion of coordination.

$$
\begin{gathered}
x^{2}=\frac{12 * S}{m n(n+1)} \\
x^{2}=\frac{12 * 652}{10 * 5(5+1)}=26,08
\end{gathered}
$$

Calculated $x^{2}$ compare with the tabular value for the number of freedom degrees $f=n-1=5-1=4$ and at the set level of meaningfulness $\alpha=0,05$.

As $\chi_{\text {calculation }}^{2}>\chi_{\text {table }}^{2}($ accordingly) $26,08>9,5)$, then $W=0,652-$ is not casual size, that't why educated results of experts' estimations make sense and can be used in further researches.

For getting reviewer results of interview in relation to meaningfulness of monitoring system's constituents of social and labour relations state the calculations were conducted according to formulas 3 and 4 . By turns the 


\section{Calculation of concordance coefficient}

Table 5

\section{for determination of reviewer expert}

\begin{tabular}{|c|c|c|}
\hline Dismiss an expert & $W$ & $x^{2}$ \\
\hline 0 & 0,6520 & 26,0800 \\
\hline 1st & 0,6247 & 22,4889 \\
\hline 2nd & 0,6222 & 22,4000 \\
\hline 3rd & 0,6494 & 23,3778 \\
\hline 4th & 0,6247 & 22,4889 \\
\hline 5th & 0,7037 & 25,3333 \\
\hline 6th & 0,6864 & 24,7111 \\
\hline 7th & 0,6469 & 23,2889 \\
\hline 8th & 0,6469 & 23,2889 \\
\hline 9th & 0,6790 & 24,4444 \\
\hline 10th & 0,6790 & 24,4444 \\
\hline
\end{tabular}

answers of interview results on one expert were removed and the minimum value of Kendall's coefficient, in fact it testifies not only about «typicalness» but also about the additional expert's informativeness. Thus, Peason coefficient $\chi_{\text {calculation }}^{2}>\chi_{\text {table }}^{2}$, and that is why educted experts' results make sense and can be used in further researches.

Generalization of conducted calculations of concordance coefficient for determination of reviewer experts is contained in table 5 .

Thus, according to table 5 the first and the fourth experts are insiders, and their estimations were taken as reviewer («standard») for the further calculations of integral index of monitoring system of social and labour relations state on Private Joint Stock Company "Monomakh". We can make an assumption, that they had additional information during an interview, in fact, they work as the leaders of subdivisions in Private Joint Stock Company "Monomakh" and their answers are more meaningful and objective. Ranking of monitoring system's constituents of social and labour relations state on meaningfulness is presented in table 6 .

Thus, according to interview's results, the most essential factor of social and labour relations state forming is the «organizationally and staffing», farther «motivational providing», «providing of normal terms of labour safety» and others like that. The least influential is the «normatively-legal providing». 
Table 6

Ranking of monitoring system's constituents of SLR state on value

\begin{tabular}{|c|l|c|c|}
\hline № & Component of monitoring systems of SLR state & Sum & Grade \\
\hline 1 & Normatively-legal providing & 1,7 & 1 \\
\hline 2 & Motivational providing & 2,15 & 4 \\
\hline 3 & Providing of normal safe terms of labour & 1,95 & 3 \\
\hline 4 & Organizationally-skilled providing & 2,4 & 5 \\
\hline 5 & Socio-cultural providing and personnel development & 1,8 & 2 \\
\hline \multicolumn{2}{|c|}{ Total } & 10 & \\
\hline
\end{tabular}

We will use expert's ponderability of monitoring system's constituents of social and labour relations state for the calculation of integral index, take the formula of multivariate average. The multivariate averages give the generalized description of every totality unit (in our calculation for a year) on a few characteristics simultaneously (in our example - it is the separate component of monitoring systems of social and labour relations state). Thus, practically always, meaningfulness of characteristic for the multivariate estimation of totality unit is often considered identical, that economically not quite unexactly. Therefore, the expert's evaluation of ponderability of every monitoring system's component of social and labour relations state was conducted for realization of more adequate integral evaluation. We conduct such calculation by formula [19]:

$$
\bar{x}^{*}=\frac{\sum_{i=1}^{n} x_{j}^{*} d_{j}}{\sum_{i=1}^{n} d_{j}}
$$

where $d_{j}$-is part (ponderability) of $i$ index on the results of interview, that was determined by reviewer expert's interview,

$x_{j}^{*}$ - the normalized values of $j$ index. We will expect these values by formula:

$$
x_{j}^{*}=\frac{x_{j}}{\bar{x}}
$$

where $x_{j}^{*}$-actual value of $j$ of monitoring syste's component of SLR state, $\bar{x}$-is normative (if such does not exist they use standard or average) value.

We will mark that at the calculation of integral index we take the results of interviwing of reviewer expert (the first and the fourth). In fact, the results of their interview are typical for this research of monitoring system of social 


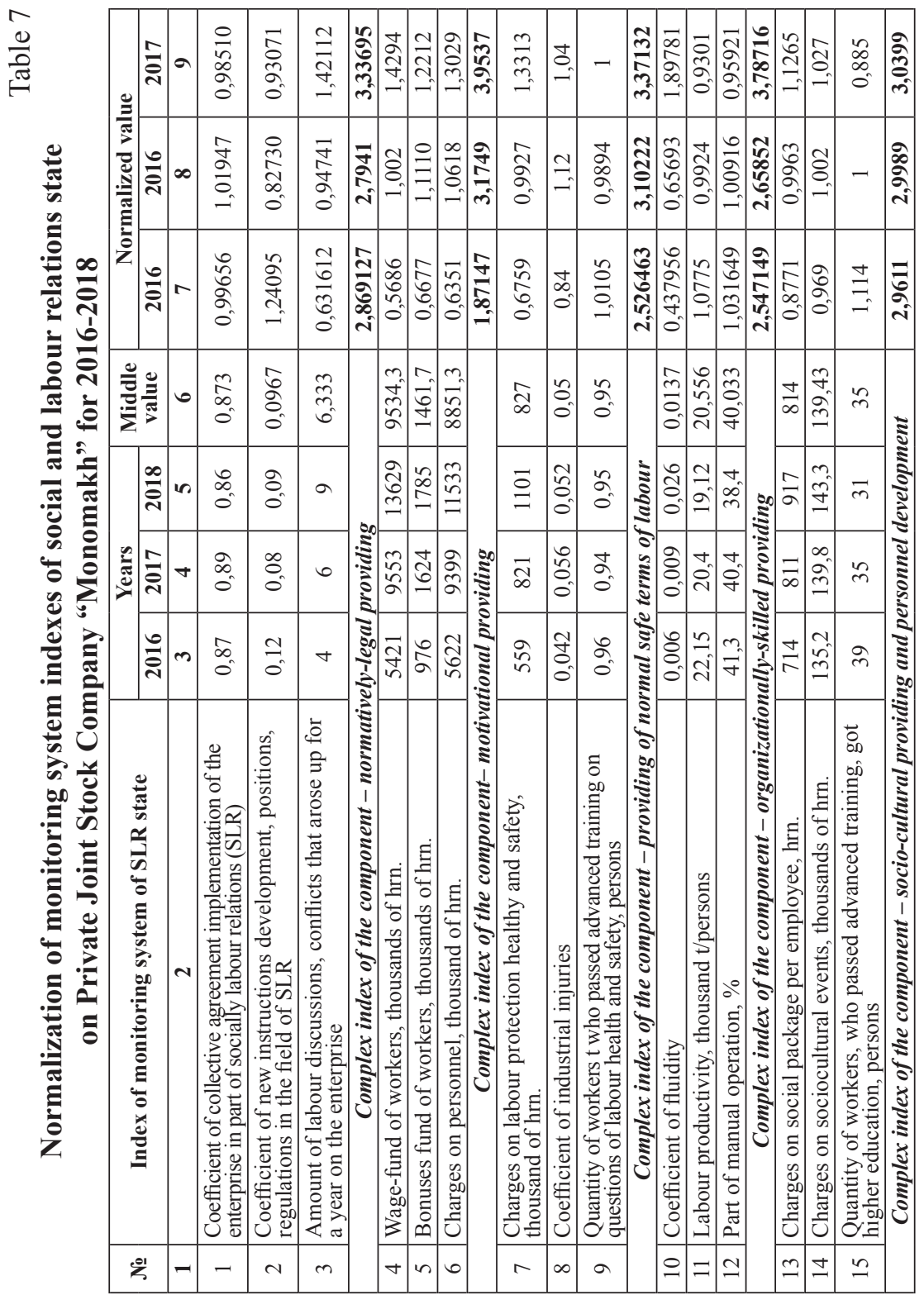




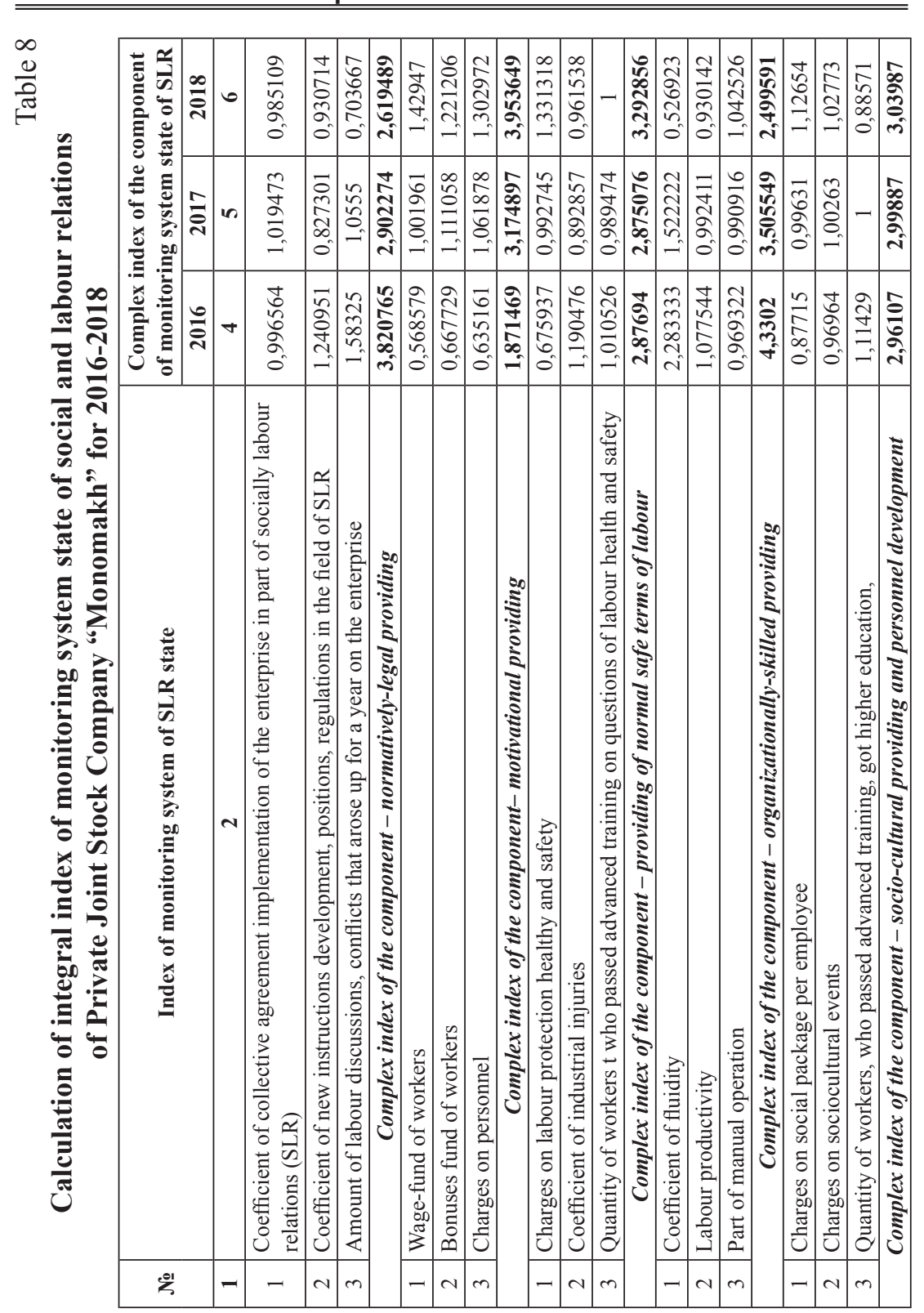


and labour relations state on Private Joint Stock Company "Monomakh". Due to the acceptance of this decision we will be able to conduct more detailed and objective analysis of the monitoring system of social and labour relations state on Private Joint Stock Company "Monomakh" for 2016-2018. Normalization of monitoring system's indexes of social and labour relations state on Private Joint Stock Company "Monomakh" is presented in table 7.

It is necessary to take into account the indexes-stimulators (their increase is desirable) and destimulators (their reduction is desirable), that is why for destimulators we expect reverse values.

In this calculation destimulator is an amount of labour discussion, injuiry at work, part of manual operation and coefficient of employee turnover. The indexes of destimulator contain the calculation of integral index as reciprocal.

Corresponding calculations are given in table 8 .

The expected complex indexes of the system give possibility to count the integral index of monitoring system of social and labour relations state on Private Joint Stock Company “Monomakh" for 2016-2018 (table 8). For ponderability of component system we accept the ponderability estimation of monitoring system's constituents of social and labour relations state of the first expert for more adequate integral evaluation (table 9).

Thus, the integral indexes of monitoring system present the sum of integral monitoring system's constituents of social and labour relations state on Private Joint Stock Company "Monomakh". The integral index of monitoring system of social and labour relations state for 2016 presents 3,2701 , for 2017 - 3,1523, for 2018 - 3,035. Expected integral estimations of monitoring system of social and labour relations state that serve as the reference-points of strategic management substantially change the value by years. In 2018 value of index substantially diminished in comparing to the previous periods. Thus, the executive management of Private Joint Stock Company "Monomakh" must use events for the improvement of tendency for providing integral index improvement of monitoring system of social and labour relations state. Such activity will assist determination of further strategic development directions of personnel. And for this purpose it is necessary to improve every indicator that influence separately.

The result certifies the reduction of social and labour relations state in 2018 in comparison with previous, but this index does not get to the cer- 
Chapter «Economic sciences»

\begin{tabular}{|c|c|c|c|c|c|c|c|c|}
\hline \multirow{9}{*}{ 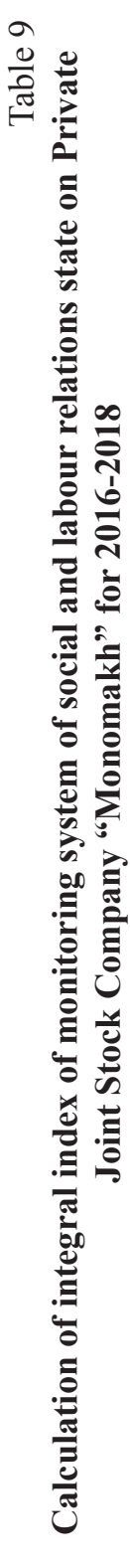 } & \multirow{3}{*}{ 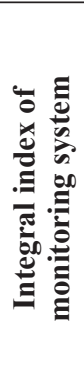 } & $\overline{\bar{c}}$ & $\begin{array}{l}\text { నू } \\
\text { ô }\end{array}$ & $\frac{2}{0}$ & 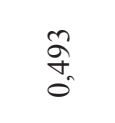 & $\frac{n}{0}$ & $\begin{array}{l}\infty \\
\stackrel{0}{0} \\
0 \\
0\end{array}$ & $\stackrel{n}{\tilde{n}}$ \\
\hline & & 을 & $\begin{array}{l}\stackrel{n}{\tilde{f}} \\
\underset{\sigma}{0}\end{array}$ & $\begin{array}{l}\tilde{n} \\
\tilde{\sigma} \\
0\end{array}$ & $\stackrel{\vec{m}}{\stackrel{\sigma}{\sigma}}$ & $\stackrel{\tilde{n}}{\sim}$ & $\begin{array}{l}0 \\
0\end{array}$ & $\frac{\stackrel{n}{n}}{n}$ \\
\hline & & 융 & $\begin{array}{l}n \\
n \\
0\end{array}$ & 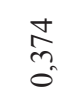 & $\begin{array}{l}\vec{g} \\
\stackrel{\sigma}{0}\end{array}$ & $\stackrel{\text { ิ }}{-}$ & 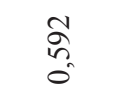 & $\begin{array}{c}\overline{0} \\
\text { ㄱ. } \\
\text { m }\end{array}$ \\
\hline & \multicolumn{2}{|c|}{ 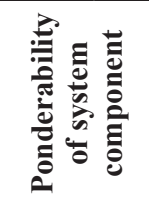 } & $\frac{n}{0}$ & $\stackrel{\overbrace{}}{\stackrel{0}{0}}$ & $\frac{n}{0}$ & $\stackrel{m}{0}$ & $\stackrel{\overbrace{}}{\tilde{0}}$ & $\stackrel{8}{-}$ \\
\hline & \multirow{3}{*}{ 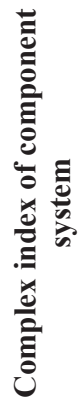 } & $\stackrel{\infty}{\bar{\sigma}}$ & \begin{tabular}{l}
\multirow{2}{\sigma}{} \\
i \\
i
\end{tabular} & 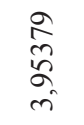 & ๗ે & $\begin{array}{l}\text { ๙े } \\
\text { i }\end{array}$ & 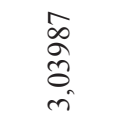 & $x$ \\
\hline & & 홍 & $\begin{array}{l}\text { ते } \\
\text { ๙ } \\
\text { ণi }\end{array}$ & 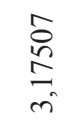 & $\begin{array}{l}n \\
\infty \\
\infty \\
\text { i }\end{array}$ & $\begin{array}{l}n \\
n \\
\text { m }\end{array}$ & $\begin{array}{l}\hat{\infty} \\
\infty \\
\curvearrowright \\
\text { i }\end{array}$ & $x$ \\
\hline & & 웅 & $\begin{array}{l}\infty \\
\infty \\
\infty\end{array}$ & $\underset{\infty}{\stackrel{N}{*}}$ & $\begin{array}{l}\hat{\alpha} \\
\hat{\infty} \\
\hat{N}\end{array}$ & $\begin{array}{l}m \\
\stackrel{m}{\sigma}\end{array}$ & $\begin{array}{l}\hat{0} \\
\text { o. } \\
\text { ते }\end{array}$ & $x$ \\
\hline & \multicolumn{2}{|c|}{ 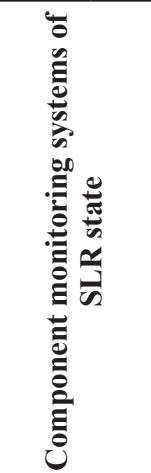 } & 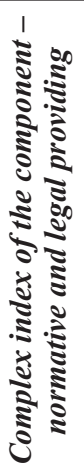 & 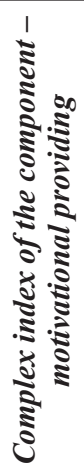 & 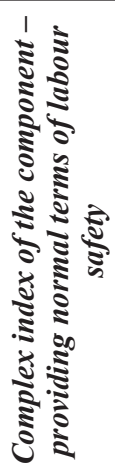 & 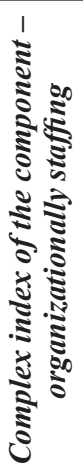 & 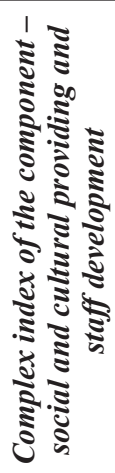 & 0 \\
\hline & \multicolumn{2}{|c|}{ 201 } & 一 & N & $m$ & $\nabla$ & in & \\
\hline
\end{tabular}


tain scale and can be used only as generalization. The benefit of this index is limited only by the estimation of level changes of the use of social and labour relations state on Private Joint Stock Company "Monomakh" that is conditioned by dynamic changes. There is more adequate method of taxonomical analysis in comparison with separate objects.

For defining how the change of indexes influences on monitoring system of social and labour relations state on Private Joint Stock Company "Monomakh", we will define the taxonomical index according to corresponding algorithm.

Stage 1. Forming of observation matrix from table $9(\mathrm{X})$, that is presented in table 10 .

Table 10

\section{Observation Matrix}

\begin{tabular}{|c|c|c|c|}
\hline \multirow{4}{*}{$X=$} & 0,573 & 0,435 & 0,392 \\
\cline { 2 - 4 } & 0,374 & 0,635 & 0,79 \\
\cline { 2 - 4 } & 0,431 & 0,431 & 0,493 \\
\cline { 2 - 4 } & 1,299 & 1,051 & 0,75 \\
\cline { 2 - 4 } & 0,592 & 0,6 & 0,608 \\
\hline
\end{tabular}

Elements of this matrix are the standardized indexes that cannot be measured. In order to conduct further calculations, it is necessary to have further standardization of values.

Stage 2. Standardize the value of observation matrix elements. For this purpose we determine the average value for every index by formula of geometrical average:

$$
\mathrm{X}_{\mathrm{j}}=\sqrt[3]{X_{1 j} * X_{2 j} * X_{3 j}}
$$

$X_{1}=\sqrt[3]{0,573^{*} 0,435^{*} 0,392}=0,4606$

$X_{2}=\sqrt[3]{0,374 * 0,635^{*} 0,79}=0,5725$

$\mathrm{X}_{3}=\sqrt[3]{0,431 * 0,431 * 0,493}=0,4507$

$X_{4}=\sqrt[3]{1,299^{*} 1,051^{*} 0,75}=1,008$

$\mathrm{X}_{5}=\sqrt[3]{0,592^{*} 0,6^{*} 0,608}=0,599$

Standardize indexes and pass to the matrix of $Z$ by formula:

$$
Z_{j}=\frac{X_{j}}{\overline{X_{j}}}
$$


Passing to the matrix $\mathrm{Z}$ is presented in table 11 .

Table 11

Matrix Z

\begin{tabular}{|c|c|c|c|}
\hline \multirow{4}{*}{$Z=$} & 1,244069 & 0,944451 & $\mathbf{0 , 8 5 1 0 9 1}$ \\
\cline { 2 - 4 } & 0,653302 & 1,109216 & $\mathbf{1 , 3 7 9 9 7}$ \\
\cline { 2 - 4 } & $\mathbf{0 , 9 5 6 1 8 8}$ & 0,956188 & 1,093737 \\
\cline { 2 - 4 } & $\mathbf{1 , 2 8 8 7 9 8}$ & 1,042746 & 0,74411 \\
\cline { 2 - 4 } & 0,986725 & 1,000059 & $\mathbf{1 , 0 1 3 3 9 3}$ \\
\hline
\end{tabular}

Stage 3. Divide characteristics into stimulators and destimulators are the basis for the construction of vector-standard. The elements of this vector have such coordinates of $\mathrm{X}_{0 \mathrm{i}}$ and formed from the certain indexes by formula:

$\mathrm{P}_{0}=(+,+,+,+,+)$,

$$
\left\{\begin{array}{c}
X_{0 j}=\max X_{j i}(\text { stimulator }) \\
X_{0 j}=\min X_{j i}(\text { destimulator })
\end{array}\right.
$$

Where $\mathrm{X}_{1}, \mathrm{X}_{2}, \mathrm{X}_{4}, \mathrm{X}_{3}, \mathrm{X}_{5}$ - stimulator,

Thus, for Private Joint Stock Company "Monomakh" the vector-standard has such coordinates:

$$
P_{0}=(0,851091 ; 1,37997 ; 0,956188 ; 1,288798 ; 1,013393)
$$

Stage 4. Determine the distance between the actual index of monitoring system of social and labour relations state and vector-standard. The distance between an initial point and point of $\mathrm{P}_{0}$ is calculated by formula:

$$
C_{j 0}=\sqrt{\sum_{i=1}^{m}\left(z_{j i}-z_{0 j}\right)^{2}}
$$

where $z_{i j}$-is the standardized value of $j$ index in the period of time $i$;

$z_{0 j}$-is standardized value of $j$ index in standard.

$$
\mathrm{C}_{\mathrm{j} 02016}=0,74 ; \mathrm{C}_{\mathrm{j} 02017}=0,492 ; \mathrm{C}_{\mathrm{j} 02018}=0,671 \text {. }
$$

Consider educted results as initial.

Stage 5. Determine the taxonomical index of monitoring system of social and labour relations state by formula $K_{i}=1-d_{i}$.

For this purpose we will expect the following indexes:

$$
\overline{c_{0}}=\frac{1}{m} \sum_{i=1}^{m} c_{i 0}
$$




$$
\begin{gathered}
\left.S_{0}=\sqrt{\frac{1}{m} \sum\left(c_{i 0}-\overline{c_{0}}\right.}\right)^{2} \\
C_{0}=\overline{c_{0}}+2 S_{0} \\
d_{i}=\frac{C_{i 0}}{C_{0}}
\end{gathered}
$$

Determine the average distance:

$$
\overline{c_{0}}=1 / 3(0,74+0,492+0,671)=0,635
$$

Find $S_{0}$ :

$$
\begin{aligned}
& S_{0}=\sqrt{\frac{1}{3}\left((0,74-0,635)^{2}+(0,492-0,635)^{2}+(0,671-0,635)^{2}\right)}=0,104 \\
& \text { Determine } C_{0}: \quad C_{0}=0,635+2 * 0,104=0,843
\end{aligned}
$$

Determine $d_{i}$ :

$$
\begin{gathered}
\mathrm{d}_{2016}=0,74 / 0,104=0,877 ; \mathrm{d}_{2017}=0,492 / 0,104=0,584 ; \\
\mathrm{d}_{2018}=0,671 / 0,104=0,796
\end{gathered}
$$

Determine the taxonomical index of monitoring system of social and labour relations state:

$$
\begin{gathered}
\mathrm{K}_{2016}=1-0,877=0,123 ; \mathrm{K}_{2017}=1-0,584=0,416 ; \\
\mathrm{K}_{2018}=1-0,796=0,203
\end{gathered}
$$

Stage 6. Build the chart of taxonomical index's dynamics of monitoring system of social and labour relations state. The dynamics of taxonomy change coefficient represents the level of monitoring management of social and labour relations state (Figure 1).

Analysing figure 1 it is possible to make conclusion, that the taxonomy index of monitoring system of social and labour relations state is unstable. Beginning from 2016 had the tendency to the increase, and attained the maximum in $2017-0,416$, but in 2018 the index diminished - 0,203, that testifies to the improper management of monitoring system of social and labour relations state on Private Joint Stock "Monomakh".

Precisely this conclusion was done on the results of integral evaluation. It is necessary to improve every indicator of influence separately for improvement 


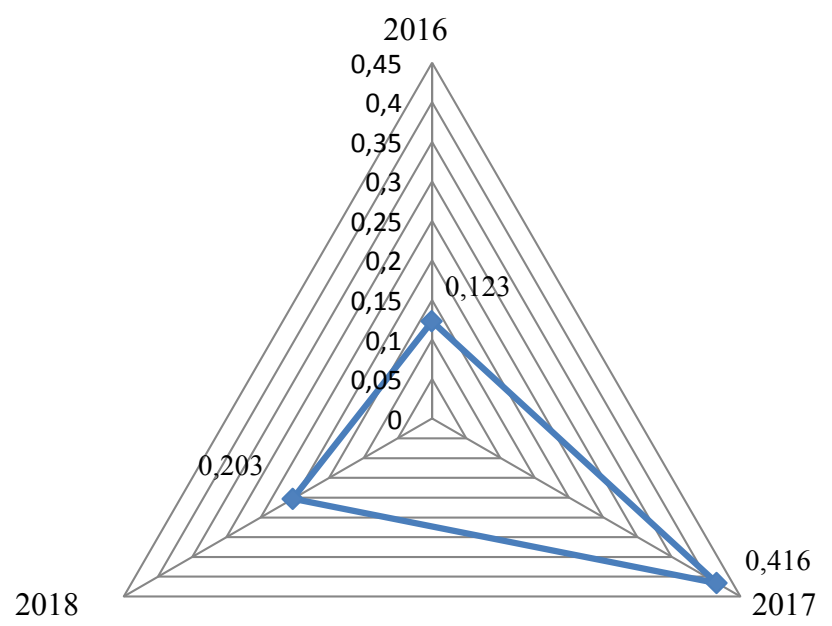

-Taxonomical index of monitoring system of social and labour relations state on Private Joint Stock Company "Monomakh” for 2016-2018

\section{Figure 1. Dynamics of taxonomical index of monitoring system of social and labour relations state on Private Joint Stock Company "Monomakh" for 2016-2018}

of social and labour relations state, monitoring of which is effective exactly with application of corresponding taxonomical index and integral evaluation.

\section{Conclusions}

Procedures and rules of social and labour relations regulations are the main base components of model organization development. Management of social and labour relations in the field of labour must be based on human values and personnel brining to the effective social dialogue. The reasonable monitoring system of SLR state of the enterprise will allow to form a valuable infobase about areas of concern and work out the events in relation to the improvement in the field of SLR with the aim of effective strategic development of the enterprise.

The modern high level of social and labour relations state on the enterprises envisages the requirement in safety and optimal labour terms; deserv- 
ing wage level and stability of its payment; additional social defence of workers; presence of social (compensative) package, development of workers through advanced training; bringing in and maintenance of workers, decline of employees turnover; adaptation to the changes; gender equality; help to the workers in critical situations; participating in the system of social partnership and others. Thus, an offer of monitoring system of SLR state allows to educe weak points, find social inventory, realize events for improvement and upgrading working life. The results necessarily will be represented positively on efficiency functioning of all enterprises.

\section{References:}

1. Bandur S. Development of social-labor relations as a prerequisite for achieving productive employment of the population. Labor market and employment. 2014. № 1. P. 8-13.

2. Gorodetska L., Shargorodska I. Methods of assessing the state of social and labor relations in the enterprise Problems of improving the efficiency of infrastructure. 2012. № 33. Available at: http://jrnl.nau.edu.ua/index.php/PPEI/article/ view/410

3. Grishnova O., Brintseva O. Responsibility of the enterprise for the personnel as a new format of building social and labor relations. Economics and Management. 2012. № 4. P. 49-56.

4. Economic-mathematical methods and models in the field of personnel management (2019): textbook / Authors' in a row. L.V. Masnyk. Kyiv: Department, 278 p. P. 241-255.

5. Kravchuk O., Rogovskaya A. Optimization of social-labor relations on the basis of activation of individual motivational mechanisms. Social-labor relations: theory and practice. Kyiv Ave., KNEU, 2017. № 2. P. 168-180.

6. Kolot A. (2004). Social and labor relations: theory and practice of regulation: monograph. Kyiv: KNEU, $230 \mathrm{p}$.

7. Korotich A. The essence of social and labor relations. Manager. Bulletin of Donetsk State University of Management. Donetsk, 2012. № 3(61). P. 30-34.

8. Lisogor L.S. Quality of working life: factors of influence and directions for improvement Demography and social policy. 2018. No. 2(18). Pp. 43-52.

9. Melnichenko O. Development of the system of social-labor relations as a precondition for economic growth Scientific Bulletin of Uzhgorod National University. 2016. Issue 7. Part 2. P. 102-105.

10. Nazarov N. Methodical approach to determining the effectiveness of social-labor relations at the enterprise Social-labor relations: theory and practice. Kyiv Ave., KNEU, 2014. No. 2. P. 363-368.

11. Sytnyk O. Integral assessment of the influence of social partnership on the development of enterprise personnel Economic analysis. TNEU. 2017. Volume 27. № 1. P. 230-239. 
12. Social and labor relations: problems of harmonization [collective monograph] (2012). M. Semykina, Z. Smutchak, S. Pasek, Y. Petrov / Ed. M. Semikina. Kirovohrad: CODE, $300 \mathrm{p}$.

13. Fomin O. The mechanism of regulation of social and labor relations on the basis of responsibility. Bulletin of Donetsk National University of Economics and Trade. M. Tugan-Baranovsky. 2013. No. 3(59). P. 46-56.

14. Shamileva L., Shastun A. Development of the Labor Sphere on the Principles of Social Responsibility: Trends, Patterns and Losses. Ukraine: Aspects of Labor. 2017. № 4. P. 29-37.

15. Hamel M. Compensation guide A Manual on Compensation Practice and Theory. 2008. № 3.71 p.

16. Henderson R.I. (2005). Compensation management in a knowledge-based world. 10th edition. Prentice Hall, $576 \mathrm{p}$.

17. Milkovich G., Newman J. (2010). Compensation. 10th edition. Boston: McGraw-Hill/Irwin, 712 p.

18. Bruce E. Hansen (2019). Econometrics. University of Wisconsin Department of Economics, $933 \mathrm{p}$.

19. Jeffrey M. (2013). Wooldridge. Introductory Econometrics: A Modern Approach. 5th edition. Michigan State University. South-Western, Cengage Learning, $910 \mathrm{p}$.

20. Frontiers in Massive Data National Analysis. Research Council (2013). Washington, D.C.: The National Academies Press, 191 p. 